\title{
Unplanned Intubation
}

National Cancer Institute

\section{Source}

National Cancer Institute. Unplanned Intubation. NCI Thesaurus. Code C141269.

An intubation procedure that was unexpected. 